\title{
KAJIAN PENILAIAN ASPEK NON-KOGNITIF SISWA DI PESANTREN AS-SUNNAHDALAM KEGIATAN PRAKTIKUM IPA POKOK BAHASAN SISTEM PENCERNAAN PADA MANUSIA
}

\begin{abstract}
Ria Yulia Gloria
Abstrak

Salah satu upaya untuk meningkatkan kualitas siswa dan ketertarikan siswa pesantren khususnya pada pelajaran IPA diantaranya adalah dengan mengadakan praktikum.Hal ini sesuai dengan pendapat Arends (2008), bahwa belajar yang baik adalah bila anda terlibat secara pribadi dalam pengalaman belajarnya (experiential Learning). Maka dilakukan penelitian dengan rumusan masalah bagaimanakah kegiatan dan kajian kemampuan non-kognitif siswa pesantren As-Sunnah dalam kegiatan praktikum uji makanan pada materi pencernaan makanan pada manusia. Hal ini bertujuan untuk mengkaji kegiatan praktikum di pesantren As-Sunnah dan mengkaji kemampuan non-kognitif siswa. Penelitian ini dilakukan di pesantren As-Sunnah dengan metode penelitian deskriptif kualitatif dan deskriptif inquiry. Hasil penelitian diperoleh sebagai berikut bahwa kegiatan praktikum di pesantren As-Sunnah yaitu di MTs Kelas VII putri jarang dilakukan karna beberapa kendala salah satunya adalah kendala sarana dan prasarana terutama ketersediaan laboratorium, namun demikian kegiatan praktikum masih tetap bisa dijalankan di ruang belajar (kelas). Untuk kajian non kognitif didapatkan kesimpulan, tingkat kesiapan siswa dalam melakukan praktikum cukup baik, keterampilan siswa dalam praktikum termasuk kedalam kategori cukup kompeten, sikap siswa sangat baik dalam kegiatan praktikum yang terdiri dari kerjasama, kedisiplinan, ketelitian, dan tanggung jawab. Sedangkan untuk respon terhadap kegiatan praktikum dapat disimpulkan bahwa siswa memiliki rasa ingin tahu terhadap hasil praktikum cukup besar, yaitu 77,8\%.
\end{abstract}

Kata kunci : Kemampuan non - kognitif, praktikum, pencernaan makanan 


\section{PENDAHULUAN}

IPA (Ilmu Pengetahuan Alam) adalah ilmu yang mempelajari alam sekitar dan semua gejala-gejalanya baik itu yang terjadi pada makhluk hidup maupun benda tak hidup. Mempelajari dan memahami sains adalah hal yang sepatutnya dilakukan oleh umat manusia terutama seorang muslim. Namun demikian beberapa pesantren banyak yang masih tidak menyadari akanpentingnya hal ini. Masih banyak pesantren yang mengabaikan pentingnya mempelajari IPA dengan lengkap yaitu mempelajari teori dan juga melakukan kegiatan praktikum. Kurangnya motivasi dari guru untuk melakukan kegiatan praktikum, kurangnya daya dukung berupa sarana dan prasarana yang berkaitan dengan praktikum sering menjadikan alasan kenapa pesantren tidak melakukan kegiatan praktikum. Hal ini membuat para santri menjadi tidak termotivasi untuk lebih mendalami dan untuk lebih memahami ilmu-ilmu yang dipelajari didalam sains. Menurut Susilo (2000), Beberapa faktor yang berpengaruh terhadap keberhasilanpembelajaran yaitu faktor guru, faktor siswa, lingkungan belajar,sarana prasarana belajar, penguasaan materi, penguasaan metode danteknik mengajar oleh guru. Selain itu, Sarana prasarana juga dapat menjadifaktor pendukung atau faktor penghambat pembelajaran.Dari pendapat tersebut tentu saja kita perlu berupaya keras agar faktor-faktor pendukung yang bisa membantu siswa belajar dapat diupayakan.

Salah satu upaya untuk meningkatkan kualitas siswa dan ketertarikan siswa pesantren khususnya pada pelajaran IPA diantaranya adalah dengan mengadakan praktikum. Kegiatan praktikum sangat perlu diberikan, hal ini karena praktikum bisa menjadi salah satu cara agar siswa bisa lebih memahami konsep-konsep yang sudah mereka terima pada saat pembelajaran di kelas. Dengan praktikum maka siswa akan mendapat pengalaman langsung karena siswa bisa langsung terlibat secara pribadi, hal ini sesuai dengan pendapat Arends (2008), bahwa belajar yang baik adalah bila anda terlibat secara pribadi dalam pengalaman belajarnya (experiential Learning). Kemudian menurut Rustaman (1995), kegiatan praktikum merupakan kegiatan pembelajaran yang memberikan pengalaman secara langsung, yang bertujuan untuk memotivasi siswa, membangun 
pemahaman konsep, mengembangkan keterampilan dasar eksperimen, mengembangkan keterampilan interpersonal dan pengembangan diri.Sehingga melalui praktikum maka tujuan belajar dapat tercapai secara terintegrasi, mencakup ranah kognitif, afektif dan psikomotor. Hal ini sejalan dengan pendapat Johnson (2007), bahwa belajar aktif yang disebut juga belajar langsung adalah yang membuat pelajaran melekat. Didukung juga oleh pendapat Sizer (1992), pembelajaran yang menekankan pada tindakan akan memberi otak kesempatan untuk merasakan dunia luar dengan cara-cara yang tak terhitung.

Pada kenyataannya dilapangan praktikum jarang sekali dilaksanakan, karena dilapangan guru lebih sering menekankan pembelajaran yang berhubungan dengan ranah kognitif saja. Hal ini sebenarnya sangat tidak sesuai dengan Garis-garis Besar Program Pengajaran (GBPP), yang mengharuskan pelaksanaan program instruksional yang seimbang antara aspek konsep dan keterampilan proses.Itulah sebabnya mengapa asesmen alternatif menjadi sangat penting. Menurut Ronis (2011), asesmen alternatif melibatkan siswa kedalam tugas yang bermanfaat dan bermakna juga dapat memungkinkan siswa menunjukkan kompetensi mereka dengan berbagai cara, hal ini karena asesmen alternatif sesuai dengan kerja otak. Salah satu asesmen alternatif yang bisa dilakukan adalah melaksanakan kegiatan praktikum.

Untuk mengetahui bagaimana kriteria siswa dalam kegiatan praktikum, maka perlu adanya kajian penilaian non-kognitif seperti kajian kemampuan dan keterampilan siswa selama praktikum.Khususnya pada siswa di pesantren, yang minim melakukan praktikum IPA. Dengan melakukan kajian penilaian non kognitif maka kita akan mengetahui bagaimana kemampuan dan keterampilan siswa pada saat praktikum berlangsung.

\section{METODE PENELITIAN}

Penelitian ini dilakukan pada siswa di pesantren As-Sunnah kota Cirebon.Siswa yang menjadi subjek dari penelitian ini adalah siswa MTs As-Sunnah yang mengikuti pembelajaran IPA di kelas VII B, dan hanya siswa kelas putri saja. 
Metode penelitian yang digunakan adalah metode deskriptif kualitatif dan deskriptif inquiry dalam menganalisis pola ilmiah yang terjadi .Sedangkan instrument yang digunakan adalah lembar observasi, dokumentasi kegiatan praktikum, angket dan pedoman wawancara. Item lembar observasi merujuk pada kriteria penggunaan alat dasar praktikum (Wirjosoemarto et al., 2000).Instrumen profil kreativitas.

Kisi-kisi angket mengungkap mengenai pembelajaran praktikum.Instrument lembar observasi, dan angket dianalisis secara kualitatif (persentasi).

Data yang dikumpulkan dalam penelitian ini adalah data yang dapat menjawab pertanyaan penelitianyang sudah ditetapkan. Yaitu data yang berupa hasilwawancara, observasi dan angket respon siswa.

Angket siswa berupa beberapa pertanyaan yang berkaitan dengan pembelajaran praktikum materi sistem pencernaan makanan, yaitu pertanyaan yang berkaitan dengan respon siswa. Menurut Sugiyono (2012) angket merupakan teknik pengumpulan data yang dilakukan dengan cara memberi seperangkat pertanyaan atau pernyataan tertulis kepada responden untuk dijawabnya. Observasi dilakukan pada saat pembelajaran berlangsung. Lembar observasi dibuat dengan indikator untuk mengukur kegiatan praktikum, yang meliputi indikator untuk mengukur kesiapan siswa, keterampilan siswa, kreativitas siswa, dan sikap siswa. Mengenai aspek-aspek non-kognitif dalam praktikum disajikan pada tabel berikut:

\section{Tabel 1. Aspek-aspek non-kognitif dalam praktikum}

uji bahan makanan

\begin{tabular}{|ll|}
\hline \multicolumn{1}{|c|}{ Aspek non-kognitif yang diukur } \\
\hline 1. & Kesiapan siswa \\
\hline a. & Kesiapan melakukan praktikum \\
\hline b. Pengetahuan menggunakan alat dan bahan \\
\hline 2. & Keterampilan siswa \\
\hline a. Menggunakan alat \\
\hline b. Membuat preparat, atau menyiapkan bahan \\
\hline c. Melakukan pengamatan \\
\hline
\end{tabular}




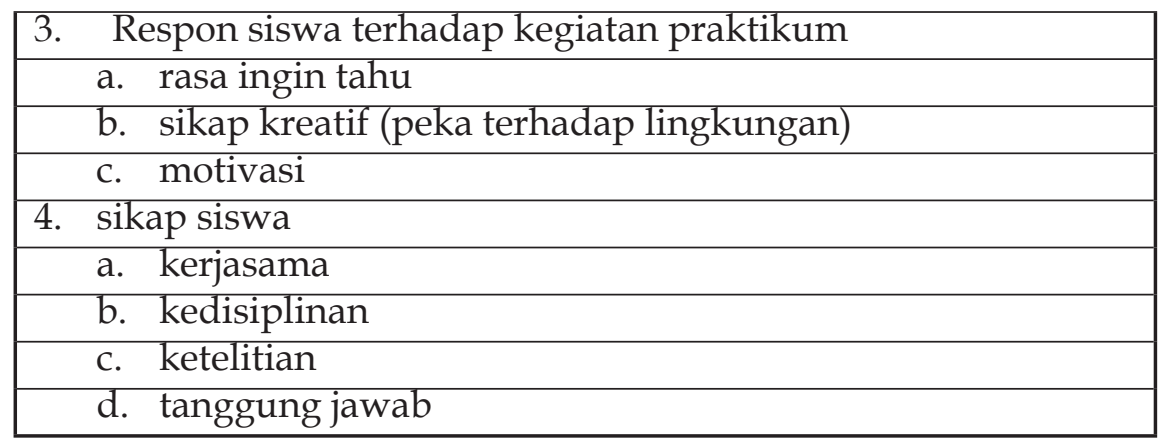

Analisis data dilakukan secara deskriptif kualitatif. Sesuai dengan prosedur analisis data deskriptif kualitatif, maka pada prinsipnya langkah-langkah analisis adalah : ((1) tabulasi data, (2) reduksi data melalui pengelompokkan (kategori), (3) interpretasi, dan (4) pengambilan kesimpulan.

\section{HASIL DAN PEMBAHASAN}

\section{KegiatanPraktikum IPA di Pesantren As-sunnah Cirebon.}

Hasil penelitian mengenai kegiatan praktikum IPA di Pesantren As-sunnah Cirebon diperoleh dari hasil wawancara, diketahui bahwa kegiatan praktikum IPA sangat jarang dilakukan, bahkan hampir tidak suka dilakukan praktikum. Meskipun demikian minat siswa terhadap IPA menurut guru sebenarnya cukup baik.

Minat yang baik pada praktikum IPA yang selama ini diketahui oleh guru IPA merupakan modal yang cukup untuk melaksanakan kegiatan praktikum, sebab hal ini sudah mengindikasikan bahwa siswa di pesantren ini pada dasarnya memiliki keinginan untuk melakukan pembelajaran yang sesuai dengan karakteristik pembelajaran IPA, dimana IPA adalah ilmu yang memerlukan pekerjaan ilmiah yang selain dipelajari secara teoritik juga harus dipelajari dengan praktik atau praktikum. Minat siswa ini juga bisa menjadi modal dasar untuk keberhasilan pembelajaran. Hal ini juga sesuai dengan pendapat Woolnough \& Allsop (dalam Rustaman, 2003), terdapat empat alasan mengenai pentingnya kegiatan praktikum, antara lain: (1) Praktikum membangkitkan motivasi belajar sains, (2) praktikum mengembangkan ketrampilan dasar melakukan eks- 
perimen, (3) praktikum menjadi wahana belajar pendekatan ilmiah, (4) praktikum menunjang materi pelajaran.

Kendala yang dianggap cukup berpengaruh terhadap kegiatan praktikum di pesantren As-sunnah adalah tidak adanya laboratorium, baik lab IPA biologi, fisika maupun kimia. Sebenarnya kendala seperti ini merupakan kendala yang umum yang termasuk kedalam kendala teknisyang juga dialami oleh beberapa sekolah lainnya, namun demikian hal ini bukanlah merupakan kendala yang tak dapat diatasi. Pada dasarnya praktikum bukan hanya bisa dilakukan di dalam ruang laboratorium. Penggunaan istilah praktikum atau yang kita kenal sebagai kegiatan laboratorium bukan hal yang harus dipermasalahkan, karna yang terpenting dari praktikum sebenarnya adalah kegiatan siswa untuk membuktikan konsep atau hukum-hukum alam, atau juga upaya pembuktian teori-teori.

Mengenai peralatan dan bahan praktikum sudah ada meskipun belum lengkap. Meskipun demikian hal ini sudah bisa dikatakan bagus, sebab lebih banyak alat-alat yang dimiliki dibandingkan dengan yang belum dimiliki, alat-alat yang sering digunakan dalam praktikum IPA hampir semuanya lengkap, seperti tabung reaksi, pipet tetes, lumpang, gelas kimia, gelas ukur, pembakar spirtus dan lain-lain.Meskipun sulit namun usaha-usaha yang kreatif dalam mengupayakan kegiatan praktikum harus dilakukan.

Kendala yang juga penting adalah guru IPA di pesantren Assunnah sama sekali belum mengikuti seminar atau pelatihantentang praktikum. Menurut Lazarowitz \& Tamir (1994) dalam Wiyanto (2008), sikap, pengetahuan, keterampilan dan perilaku guru dapat mempengaruhi keberhasilan dalam pencapaian tujuan belajar di laboratorium. Mengajar di laboratorium memerlukan penguasaan keterampilan proses ilmiah (metode ilmiah) dan pengetahuan materi subyek, serta memerlukan pengetahuan khusus tentang iklim kelas dan cara mengelolanya.

\section{Tingkat Kesiapan siswa dalam kegiatan praktikum}

Data mengenai tingkat kesiapan dalam kegiatan praktikum, diperoleh dengan melakukan observasi. Tingkat kesiapan siswa terdiri atas kesiapan melakukan praktikum dan pengetahuan meng- 
gunakan alat dan bahan.

Tabel 2. Tingkat Kesiapan Siswa

\begin{tabular}{|c|l|c|}
\hline No. & Aspek non kognitif kesiapan siswa & $\begin{array}{c}\text { Persentase } \\
\mathbf{( \% )}\end{array}$ \\
\hline 1. & Kesiapan melakukan praktikum & 89,87 \\
\hline 2. & $\begin{array}{l}\text { Pengetahuan menggunakan alat dan } \\
\text { bahan }\end{array}$ & 51,8 \\
\hline
\end{tabular}

Nilai yang diperoleh untuk kesiapan siswa adalah 89,87\% siswa memiliki kesiapan melakukan praktikum yang terdiri dari sudah siap dengan apa yang akan dipraktikumkan (mengetahui judul dan tujuan praktikum), membawa perlengkapan praktikum, dan berpenampilan rapi. Hal ini termasuk dalam kriteria sangat baik. Sedangkan untuk kriteria pengetahuan menggunakan alat dan bahan, siswa kurang memiliki pengetahuan menggunakan alat dan bahan, hal ini bisa dilihat dari rata-rata yang diperoleh untuk pengetahuan menggunakan alat dan bahan yaitu hanya sebesar 51,8\%. Nilai seperti ini dapat membuktikan bahwa siswa dipesantren putri AsSunnah belum begitu terbiasa dengan praktikum, sehingga dalam menggunakan alat dan bahan praktikum hanya beberapa orang saja yang mampu menggunakannya.

\section{Keterampilan siswa dalam kegiatan praktikum}

Nilai keterampilan siswa diperoleh melalui observasi, yang meliputi pengetahuan tentang prosedur kerja,ketepatan memilih alat dan bahan, hasil pengamatan, danketepatan menyusun laporan. Untuk lebih jelasnya hasil observasi disajikan dalam grafik nilai keterampilan siswa. jenis keterampilan ketepatan menyusun laporan memiliki rata-rata nilai tertinggi yaitu 2,9. Sedangkan nilai ratarata terkecil adalah nilai untuk jenis keterampilan hasil mengamatan yaitu 2,3. Banyak faktor yang membuat nilai pada jenis keterampilan menyusun laporan lebih besar diantara yang lainnya, karena menyusun laporan sudah ada panduan tertentu yang memudahkan siswa untuk mengikuti urutan penulisan laporan yang benar. Se- 
dangkan untuk jenis keterampilan hasil pengamatan memerlukan ketelitian dan pemahaman yang cukup agar dapat menuliskan hasil pengamatan yang dilakukan ketika praktikum, rendahnya kemampuan siswa dalam mengamati hasil praktikum dapat menjadi kendalanya, hal ini juga dapat menjelaskan bahwa siswa jarang sekali melakukan praktikum sehingga kurang terlatih dalam melakukan pengamatan.

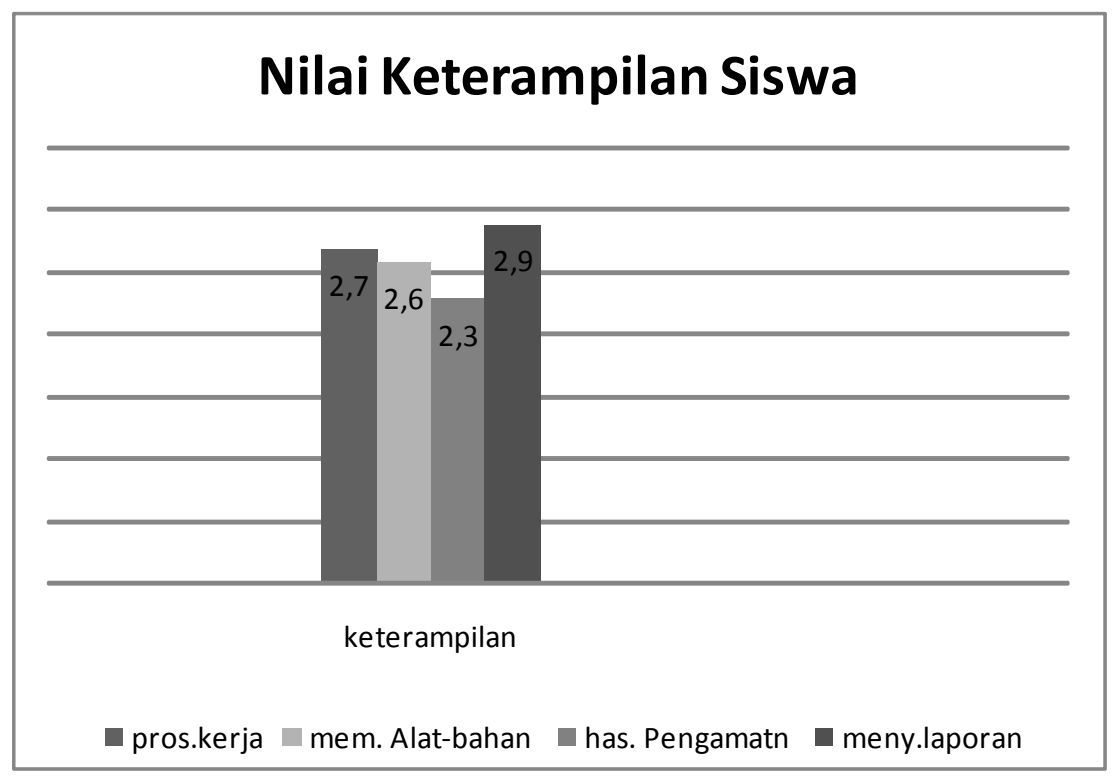

Gambar 1. Grafik Nilai Keterampilan Siswa

Dapat disimpulkan bahwa keterampilan siswa dalam kegiatan praktikum termasuk kategori cukup kompeten, artinya siswa cukup kompeten dalam hal pengetahuan tentang prosedur kerja, ketepatan memilih alat dan bahan, hasil pengamatan dan ketepatan menyusun laporan.Dari keempat jenis keterampilan dalam praktikum, keterampilan menyusun laporan memiliki nilai tertinggi yaitu 2,9 yang berarti rata-rata siswa mampu menyusun laporan namun kesimpulan masih ada yang kurang tepat. 


\section{Sikap siswa dalam Kegiatan Praktikum IPA}

Sikap siswa dalam kegiatan praktikum diperoleh dengan melakukan observasi. Sikap siswa yang diamati meliputi empat indikator yaitu : (1) kerjasama, (2) kedisiplinan, (3) ketelitian, dan (4) tanggung jawab.

Sebanyak $48,15 \%$ siswa memiliki sikap baik pada kegiatan praktikum IPA, dan 51,85\% bersikap sangat baik, artinya rata-rata Nilai sikap sangat baik yang diperoleh bisa menjadi indikator baiknya sikap siswa di pesantren As-Sunnah yang rata-rata memiliki tingkat disiplin yang tinggi. Sebenarnya hal ini dapat menjadi modal utama dalam keberhasilan mengajar bagi guru.

Hal ini juga didukung oleh pendapat Decaprio (2013), bahwa kegiatan di laboratorium atau yang dinamakan praktikum akan memiliki tujuan-tujuan yang akan dicapai yaitu teliti dalam pengamatan, mampu menafsirkan hasil percobaan, mampu merencanakan dan melaksanakan percobaan, terampil dalam menggunakan alat, tumbuh sikap positif terhadap kegiatan praktikum, dan menemukan kebenaran secara ilmiah. Selain itu pentingnya ketelitian saat melakukan praktikum berhubungan dengan tata tertib laboratorium, yang merupakan kriteria yang penting untuk menjaga kelancaran, keselamatan, serta keamanan pengguna laboratorium (Wirjosoemarto, et al, 2004). Hal ini karena bekerja dilaboratorium tidaklah sama dengan bekerja di tempat lain. Bekerja di laboratorium memerlukan ketrampilan, kecermatan, dan kehati-hatian yang cukup tinggi, agar tidak terjadi kegagalan di dalam melaksanakan kegiatan.Karna kecelakaan mungkin saja terjadi di laboratorium terutama disebabkan karena faktor manusia, yaitu kecerobohan atau ketidak telitian dan ketidaktahuan.

Untuk lebih jelasnya perbandingan sikap siswa yang meliputi kerjasama, kedisiplinan, ketelitian dan tanggung jawab dapat dilihat pada gambar 2.Nilai kedisiplinan memperoleh nilai tertinggi yaitu 2,9 ini menunjukkan bahwa rata-rata siswa memiliki kedisiplinan yang baik. 


\section{Nilai Sikap Siswa}

2,9

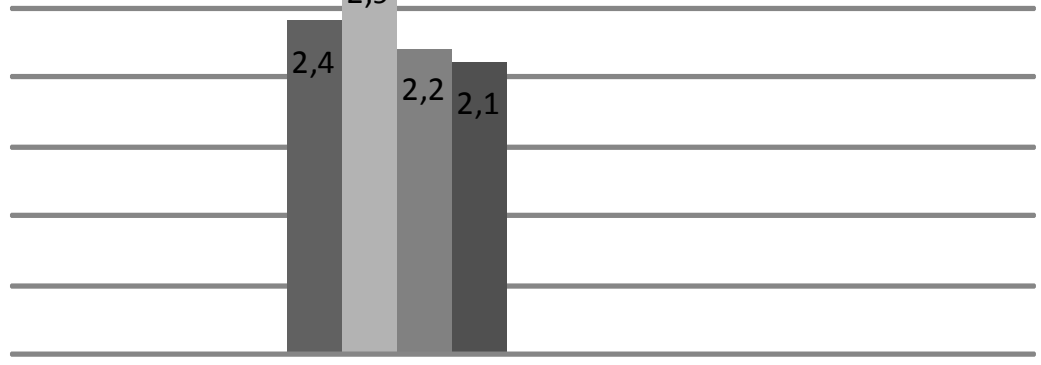

Sikap Siswa

- kerjasama $\quad$ kedisiplinan

\section{Gambar 2. Grafik Nilai Sikap Siswa}

\section{Repon Siswa terhadap kegiatan Praktikum IPA}

Hasil respon siswa terhadappraktikum uji makananpada materi pencernaan makanan pada manusia, di pesantren As-Sunnah MTs kelas VII putri didapatkan dari lembar angket yang sudah diberikanpada siswi yang menjadi subjekpenelitian. Hasilnya sebanyak $77,8 \%$ siswa menjawab setuju, ini adalah jawaban siswa yang terbanyak. Hanya sedikit sajasiswa yang menjawab setuju untuk rasa ingin tahu terhadap materi IPA.Dari hasil angket kita mendapatkan kenyataan yang sebenarnya saling bertentangan, dimana pada umumnya jika siswa memiliki rasa ingin tahu terhadap hasil dari praktikum maka siswapun akan besar pula rasa ingin tahunya terhadap nilai IPA. Namun sebaliknya dari siswa yang ada di pesantren AsSunnah ini, yaitu siswa putri MTs yang menjadi subjeknya, dimana rasa ingin tahu yang besar terhadap hasil praktikum tidak diikuti rasa ingin tahu terhadap materi IPA. Ada kejanggalan yang terlihat disini, namun kita tetap masih dapat mencari alasan dari hasil tersebut. Dari latar belakang siswa yang jarang melakukan praktikum IPA (berdasarkan hasil wawancara dengan guru) maka siswa akan 
sangat terangsang untuk dapat mengetahui bagaimana hasil dari praktikum (dalam hal ini adalah praktikum uji bahan makanan), namun para siswa sebenarnya masih meragukan tentang manfaat dari materi IPA, sehingga mereka tak begitu ingin mengetahui dengan materi IPA, sebagian besar mereka lebih tertarik dengan materi-materi yang berhubungan dengan pelajaran agama (ini masih berupa dugaan saja).

\section{KESIMPULAN}

Kegiatan praktikum IPA di pesantren As-sunnah, dalam hal ini di kelas VII belum sepenuhnya dilakukan. Tidak adanya laboratorium dan kemampuan guru menjadi kendalanya. Sedangkan hasil penilaian non-kognitif adalah sebagai berikut:

1. Tingkat kesiapan siswa dalam melakukan praktikum memiliki nilai yang cukup baik hal ini berarti siswa siap melakukan praktikum.

2. Keterampilan siswa dalam melakukan praktikum dapat disimpulkan bahwa dalam kegiatan praktikum,keterampilan siswa termasuk kategori cukup kompeten, artinya siswa cukup kompeten dalam hal pengetahuan tentang prosedur kerja, ketepatan memilih alat dan bahan, hasil pengamatan dan ketepatan menyusun laporan.

3. Sikap siswa dalam kegiatan praktikum adalah siswa memiliki sikap yang sangat baik dalam kegiatan praktikum IPA, mereka memiliki nilai kerjasama, kedisiplinan, ketelitian, dan tanggung jawab yang sangat baik.

4. Respon siswa terhadap kegiatan praktikum, Dapat disimpulkan bahwa siswa memiliki rasa ingin tahu terhadap hasil praktikum sangat besar. 


\section{DAFTAR PUSTAKA}

Arends, Richard I. (2008). Learning To Teach. Yogyakarta: Pustaka Pelajar.

Campbell, Neil A. dkk. Biologi Jilid III. Jakarta : Erlangga

Decaprio Richard. 2013. Tips Mengelola Laboratorium Sekolah.Jogjakarta: Diva Press.

Hodson, D. (1996). Laboratory work as scientific method : three decades of confusion and distortion. Journal of Coriculum Studies, 28:2, 115-135.

Johnson, Elaine B (2007). Contextual Teaching and Learning. Bandung : MLC

Muslich, Masnur, Drs., M.Si. (2010). Authentic Assesment : Penilaian Berbasis Kelas dan Kompetensi. Bandung: Refika Aditama.

Rustaman, N.Y. (1995). Peranan Praktikum dalam Pendidikan Biologi .Makalah untuk PelatihanLaboratorium dan Teknisi MIPA LPTK. Proyek PS2PT. Dirjen Dikti Depdikbud. Jakarta.

Ronis, Diane. (2011). Asesmen sesuai Cara Kerja Otak.Jakarta : Indeks

Sizer, T. R. 1992. Horace's School: Redesigning the American High School. Boston : Houghton Mifflin.

Sudargo, Fransisca., Dr., M.Pd, dkk. (2003). Meningkatkan kemampuan mahasiswa calon guru Biologi dalam melakukan praktikum Genetika sebagai penunjang pemahaman.Seminar Pro- 
ceeding National Seminar on Science and Mathematics Education, A 51-1-A51-7.

Sudjana, Nana. 2004. Penilaian Hasil Proses Belajar Mengajar. Bandung: PT. Remaja Rosdakarya

Sugiyono. 2012. Metode Penelitian Pendidikan Pendekatan Kuantitatif, Kualitatif, dan RED. Bandung: Alfabeta

Supriyadi, M.Pd. (2011). Srategi Belajar Mengajar. Surabaya : Cakrawala Ilmu.

Susilowarno, Gunawan. Dkk. 2007. Biologi SMA untuk SMA kelas XI. Jakarta : Grasindo

Wirjosoemarto, K. Adisenjaya, Y.H. Supriatno, B. \& Riandi (2000). Teknik Laboratorium. Bandung : FPMIPA-UPI.

Wiyanto, Dr., M.Si. (2008). Menyiapkan Guru Sains mengembangkan Kompetensi Laboratorium.Semarang : Universitas Negeri Semarang Press. 